\title{
Complutum
}

ISSN: 1131-6993

\section{Phytomorphic carnelian pendants in the Late Bronze and Iron Ages of the Iberian Peninsula: origin, distribution, and significance}

\author{
Francisco B. Gomes ${ }^{1}$
}

Recibido: 16/12/2020 / Aceptado: 20/04/2021.

\begin{abstract}
First highlighted as possible markers for early, $2^{\text {nd }}$ millennium BCE contacts between the Iberian Peninsula and the Eastern Mediterranean, phytomorphic carnelian pendants have become a significant part of the discussion on that subject. However, a number of new finds which have taken place in recent years have transformed the available image regarding both the geographic distribution and the chronological setting of these pieces. An updated overview is presented here, which suggests they should now preferably be considered as part of the array of prestige goods introduced in the Far West by Phoenician trade between the later stages of the Late Bronze Age and the Early Iron Age. Keywords: Adornments; Carnelian; Aegyptiaca; Mediterranean Trade; "Pre-colonization"; Phoenician Trade.
\end{abstract}

\section{[es] Los colgantes fitomorfos en las Edades del Bronce y del Hierro de la Península Ibérica: origen, distribución y significado}

Resumen: Valorizados por primera vez como posibles marcadores de contactos precoces entre la Península Ibérica y el Mediterráneo Oriental todavía durante el II milenio a.n.e., los colgantes fitomorfos de cornalina se han convertido en una parte importante de la discusión sobre ese tema. Sin embargo, nuevos hallazgos acaecidos en fechas recientes transformaron la imagen disponible sobre la distribución geográfica y la cronología de estos abalorios. En esta sede se presenta una síntesis actualizada, que sugiere que deberían preferentemente considerarse como parte del abanico de bienes de prestigio introducidos en el Extremo Occidente por el comercio fenicio entre las etapas terminales del Bronce Final y la I Edad del Hierro.

Palabras clave: Abalorios; Cornalina; Aegyptiaca; Comercio Mediterráneo; "Precolonización"; Comercio Fenicio.

Sumario: 1. Phytomorphic carnelian pendants, between the East and the West. 1.1. The use of carnelian in the Near East: a brief introduction. 1.2. Phytomorphic carnelian pendants: definition, typology, and iconography. 1.3. Origin and diffusion of phytomorphic carnelian pendants, from Egypt to the Far West. 2. Phytomorphic carnelian pendants in the Iberian Peninsula: distribution, chronology, and uses. 2.1. The corpus: phytomorphic carnelian pendants in the Far West. 2.2. The chronology, distribution, and uses of phytomorphic carnelian pendants in Iberia: Comments on the corpus. 3. The significance of carnelian pendants in Iberian Protohistory: some concluding remarks. Bibliography.

Cómo citar: Gomes, Francisco B. (2021): Phytomorphic carnelian pendants in the Late Bronze and Iron Ages of the Iberian Peninsula: origin, distribution, and significance. Complutum, 32(1): 29-47.

\footnotetext{
UNIARQ - Centre for Archaeology of the University of Lisbon; School of Arts and Humanities of the University of Lisbon; Foundation for Science and Technology, Alameda da Universidade 1600-214 Lisbon, Portugal

E-mail: franciscojbgomes@gmail.com

Tlf.: +351916119258
} 


\section{Phytomorphic carnelian pendants, between the East and the West \\ 1.1. The use of carnelian in the Near East: a brief introduction}

Due no doubt to its bright and fetching colour, carnelian was used since a very early date in the Near East and the Eastern Mediterranean for the production of beads, a use which goes back as early as the PPNB/ Aceramic Neolithic (Groman-Yaroslavski \& Bar-Yosef 2015; Alarashi 2016; Rigaud et al. 2017: fig. 7, k; Moutsiou \& Kassianidou 2019). However, the relative scarcity of this reddish variant of calcedony in the region precluded any widespread use of carnelian until significantly later.

In fact, only in the third millennium BCE (from here on, except otherwise indicated, all dates are BCE) does carnelian start to play a prominent role in the Near East, as a consequence of the emergence of complex polities in the Indus Valley which had direct access to the rich carnelian deposits of the Gujarat region of north-western India (Roux 2000). The raw material extracted there was used to produce technically complex and highly distinctive adornment elements which were exported in significant numbers to Mesopotamia and beyond (Inizan 1999; 2000; Debrabant 2016: 203-7).

While there are certainly other, minor sources of carnelian in Western Asia (Inizan 1999: fig. 1; Brunet 2009; Debrabant 2016: 236-45), both the typology of the objects themselves (Reade 1979; Inizan 1999; 2000) and the analysis of the techniques used in their production (Matarasso \& Roux 2000; Roux 2000; Debrabant 2016) are highly distinctive and point to an origin in the Indus area.

However, with the demise of the Indus Valley polities, the predominance of Indian carnelian gives place in the second millennium to a more complex panorama, in which other sources for this prized semi-precious stone played a critical role, such as those located in the Caucasus (Brunet 2009; Debrabant 2016), but especially those accessible through the Nile Valley.

The use of carnelian in Egypt, which is also attested since very early, Predynastic times (Xia 2014), does in fact experience a significant increase during this time, fuelled by the exploration of the sources for this raw material available in the Western Desert, and especially in Nubia (Harrell \& Storemyr 2009: 51) after it came under Egyptian control. The increase in popularity of carnelian during the New Kingdom is in fact well documented (Xia 2014: 118), as is its symbolic significance (Aufrère 1991: 554-6).

\subsection{Phytomorphic carnelian pendants: definition, typology, and iconography}

Among many other elements -jewellery, adornments, amulets, etc.- which began to be produced in this material at this time, one specific type of pendant stands out for its characteristic, albeit somewhat ambiguous iconography ( $c f$. infra), and for the widespread distribution it achieved beyond the borders of Egypt (Fig. 1).

These pendants have a characteristic shape, with a base roughly trapezoidal in section and a rounded body topped by an elongated stemlike appendage transversally perforated for suspension. They have usually been recognized as direct or indirect representations of a floral element, although the exact identification of that element has been the subject of some debate ( $c$. infra). Two variants have been recognized among the known material, comprising, on the one hand, rounded, tri-dimensional pieces (naturgetraue Variante) (e.g., Fig. 2 and 3, n. 2), and, on the other, pieces with flat backs or, more rarely, bi-dimensional (stilisierte Variante) (e.g., Fig. 2 and 3, nn. 1, 3, 4, etc.) (Müller-Winkler 1987: 277).

First individualized by H. Beck and included in his Group XXVI as Type B.3.d (Beck 1928: 28-9), these pendants have since been listed in most typologies for pendants and amulets, both in Egypt and beyond. They correspond to C. Müller-Winkler's Type M102 (Müller-Winkler 1987: 277-80 and Taf. XXVI), to P. McGovern's Type IV.F.5.a-b (McGovern 1985: 47-8 and Pl. 11), to A. Golani's Type II.4 pendants (Golani 2013: 165-6 and fig. 23), to H. Ben Basat's Type 1.H (Ben Basat 2011: 149-50) and to I. Mataresi's Type PD8 (Matarese et al. 2015: 127-8 and fig. 10).

As mentioned above, there has been some disagreement among researchers regarding the identification of the specific element represented in these pendants. H. Beck used the rather ambiguous designation "lotus seed-vessel pendant" (Beck 1928: 28-9), which was retained by $\mathrm{P}$. McGovern, who furthermore claimed that this identification was fairly consensual (McGovern 1985: 47). 
However, a bibliographic overview suggests that was not the case, and that the arguments of R. Merrillees (1962: 291-2) against the idea that these pendants are in any way related to lotus capsules (Lotus sp.) carried significant weight, as did his hypothesis that they instead represented the capsules of opium poppies (Papaver somniferum), which was retained until much later, namely in the works of C. Herrmann (1985: 128-31; 2006: 231-3), who only recently changed his view and now classifies these pendants as representations of pomegranates (Punica granatum) (Herrmann 2016: 253-62).
Within Egyptological literature, recent works seem however to favour the identification of these pendants as representations of cornflowers (Centaurea depressa), which had already been suggested by $\mathrm{C}$. Müller-Winkler (1987: 277-80). This is an exotic plant, indigenous to the Levant but not to Egypt, where it seems to have been introduced as an ornamental garden flower during the early $18^{\text {th }}$ Dynasty (Hepper 1990: 14). In recent years, J. Phillips, among others, has retained the identification of these pieces as "cornflower beads" (Phillips 2003; 2008: 140-5).

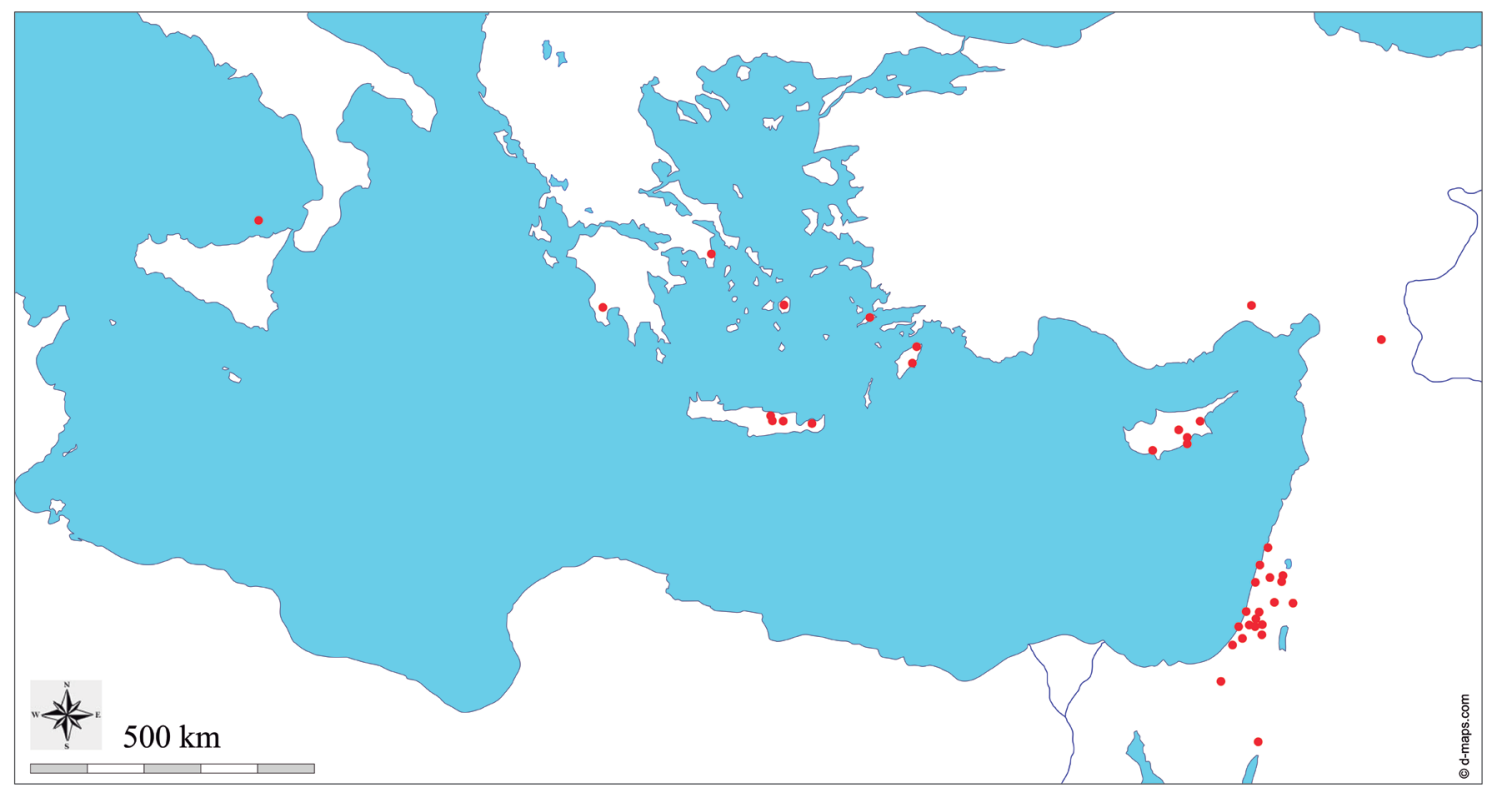

Figure 1 - Distribution of phytomorphic carnelian pendants in the Eastern and Central Mediterranean (excluding Egypt). Cartographic base: d-maps.com.

This being said, the latter author has also very perceptively pointed out that these pendants, produced in various raw materials of different colours, more likely represent different floral species (Phillips 2003: 546), and suggests that carnelian examples might represent corn poppies (Papaver rhoeas) (Phillips 2008: 145; $c f$. Ben Basat 2011: 84), yet another prized flower in Ancient Egyptian gardens (Hepper 1990: 16).

While this last hypothesis seems, at present, the most compelling one, the truth is that the very schematic nature of the representation, coupled with the ambiguity generated by changing interpretations throughout the history of research, does not recommend a definite identification of the motif represented in these pendants, and certainly not in a work dealing with examples that have travelled quite far and likely crossed several cultural borders, and which may have been resignified in the process. A conscious choice has therefore been made here to designate these pieces using the more general label "phytomorphic pendants".

\subsection{Origin and diffusion of phytomorphic carnelian pendants, from Egypt to the Far West}

This type of pendants first appears in Egypt in mid- $18^{\text {th }}$ Dynasty contexts dated to the reign of Tuthmose III or, at the latest, of Tuthmose IV (Phillips 2003: 546-7), but they do not seem to become popular until the later Amarna Period, in which they were widely appreciated and produced in large amounts, both in carnelian 
and in other materials, namely faïence (Phillips 2003: 546-7; 2008: 141). Their popularity extended throughout the later New Kingdom, and while they seem to have become less common after the end of the $19^{\text {th }}$ Dynasty, their use seems to be well documented until the Late Period (Phillips 2003: 547).

Due to the political and economic projection of Egypt in the Levant and the Eastern Mediterranean during the New Kingdom (van de Mieroop 2007), this type of pendants became relatively widespread beyond the Nile Valley during the Late Bronze Age (Fig. 1). In the Levant, carnelian examples first appear during the Late Bronze Age (LBA) IIA (ca. 1400 - 1300), namely in Megiddo (McGovern 1985: 120, n.144) and possibly in Tell Beit Mirsim (Golani 2004: Fig. 4.1, n.7), shortly after they became fashionable in Egypt itself.

However, these pendants only become relatively common in the area during the LBA IIB (ca. $1300-1200$ ), when they come to be comparatively widespread, with well-documented examples in Megiddo (McGovern 1985: 120-1, nn.144, 155-7), Beth Shean (id.: 120, nn.143, 147-50; Golani 2009: 620-1), Beth Shemesh (McGovern 1985: 120, n.151), Lachish (id:: 120, n.152), Tell es-Sa'idiyeh (Tubb 1988: fig. 48b), Tell el-Far'ah South (Herrmann 2016: 258, nn.925-53) and Ekron (Herrmann 2006: 232, n.459). Other examples can only be generally dated to the LBA II, such as the pieces from Tell Jemmeh (Golani 2014: 904) and Tell Abu Hawām (Hamilton 1935: Pl. XXV/395/h).

Slightly later examples, from the end of the LBA or the beginning of the Iron Age (IA), are documented in Beth Shean (Herrmann 2016: 255, nn.683-9), Beth Shemesh (id.: 256, nn.692-714), Deir el-Balah (id.: 256-7, nn.715-905), Tell el-Far'ah South (id.: 258, nn.906-24), Timna (McGovern 1985: 57, note 47) and, further inland, in Syria, in the necropolis of Mari (Caubet \& Yon 2006: Fig. 1). Yet another example that can only be attributed to a very wide chronological bracket, covering the LBA and IA I, was retrieved in Gezer (Macalister 1912: fig. 289, n.31).

While there is a clear decrease in the number of these pendants during the IA, their percentual representativeness in the bead/pendant assemblages seems to remain stable during this period, at least in the southern Levant (Ben Basat 2011: 167). Examples dating specifically from IA IA $(c a .1200$ - 1150) were retrieved in Ashkelon (Herrmann 2006: 231, nn.453-4), Megiddo (Herrmann 2016: 259, nn.957-64), and possibly in Tell Miqne - Ekron (Golani 2016: 484; Herrmann 2016: 232-3, nn.460, 462). Examples from Mesopotamia, namely from Babylon, dated to the end of the Kassite period (Reuther 1926: P1. 58, n.50), could also fall within this chronological interval.

Several more examples can be dated to the IA IB (ca. $1150-1000)$, a period in which phytomorphic pendants are present in Megiddo (Herrmann 2016: 260-1, nn.1001-2, 1005), Tel Dor (Ben Basat 2011: 70-1), Ashdod (Golani \& Ben Shlomo 2005: 250, fig. 4.1, n.7) and Tell Miqne - Ekron (Herrmann 2006: 2323 , n.463). Some examples from Beth Shean (Herrmann 2016: 259, nn.965-96), Tell Rehov and possibly Tell es-Safi (Ben Basat 2011: Table 7.37) can only be generically dated to the IA I period, while at least one piece from Tel Dor dates from a transitional horizon between the IA I and II (Ben Basat 2011: 70-1).

While some authors have argued that these pendants become merely residual during the IA II (ca. 1000 - 586) (McGovern 1985: 48), recent work suggests that the number of pieces dating from this phase is far from insignificant (Golani 2013: 165-6). Carnelian phytomorphic pendants have in fact been found in IA II contexts in Beth Shemesh, in a $10^{\text {th }}$ century context, in Beth Shean, in contexts ranging from the $10^{\text {th }}$ to the $8^{\text {th }}$ century, in Akhziv, in contexts dating from the $10^{\text {th }}$ to the $7^{\text {th }}$ century, in Megiddo, in Strata equally dated between the $10^{\text {th }}$ and the $7^{\text {th }}$ centuries, in Lachish, in an $8^{\text {th }}$ century burial cave, in Ashqelon, in a $7^{\text {th }}$ century horizon, and in Kadesh Barnea, in layers dating between the $7^{\text {th }}$ and as late as the $4^{\text {th }}$ century (ibid., with bibliography).

Further Levantine examples, albeit without clear context, could also be mentioned here, such as two examples from Israel recently published by C. Herrmann (2016: 258, nn.9545), or one unstratified piece from Gözlü Kule, in Cilicia (Goldman 1956, fig. 422/201).

In the Levant, phytomorphic carnelian pendants can therefore be said to have had a relatively long period of use and circulation, and perhaps even of production ( $c f$. Ben Basat 2011: 186), a fact that has significant implications for the study and interpretation of their diffusion throughout the Mediterranean Basin, as shall be noted later.

The diffusion of this very characteristic type of pendant was not, however, restricted to 
the Near East. During the LBA they became in fact relatively widespread in the Eastern Mediterranean, with significant concentrations in Cyprus, Crete, and the Aegean.

The island of Cyprus, in particular, has yielded a significant number of pieces, and has been considered as a possible distribution centre for this type of pendants (Matarese et al. 2015: 132). Examples from the island include the finds from a LC IIC (ca. 1300 - 1200) tomb in the necropolis of Kition, from probable LC IIIA ( $c a .1200$ - 1100) contexts in Hala Sultan Tekke, from an advanced LC IIIB ( $c a$. $1100-1050)$ tomb in the necropolis of Kaloriziki, from a context in the acropolis of Idalion generically dated in the LC III, and from several contexts in Enkomi roughly contemporary with the ones mentioned before (id.: 127, with bibliography; $c f$. Phillips 2003: 547).

Yet another significant concentration of phytomorphic carnelian pendants can be found in Crete. The examples from the island have been well studied in recent years by J. Phillips, who rightly classifies them as aegyptiaca (Phillips 2008: 140-5; cf. Phillips 2003). Several carnelian examples dating from the LM IIIA (ca. $1400-1300)$ and later are known, namely the pieces from the necropolis of Episkopi (LM IIIA-B) and Khamaizi Phatsi (Sub-Minoan to Protogeometric), to which can be added a much later example found in the dumps of the Demeter Sanctuary in Knossos, in a context dated between the $5^{\text {th }}$ century and the $2^{\text {nd }}$ century $\mathrm{CE}$; other examples without clear contexts have been found in the Dikte Cave (ibid.).

Further north, this type of pendant is also well attested in the Aegean, namely in Rhodes, in early/ middle LH IIIC (ca. 1200 - 1100) tombs in the necropolis of Ialysos and Pylona, in Kos, in an early LH IIIC (ca. $1200-1150)$ tomb in the necropolis of Langada, as well as in Naxos, in a tomb dating from the end of the
LH IIIC (ca. 1100 - 1050) from the necropolis of Kamini (Matarese et al. 2015: 127 and 1434, with bibliography).

Occurrences in mainland Greece are less common, but significant examples can nonetheless be mentioned from the necropolis of Perati, in Attica, where several carnelian phytomorphic pendants were retrieved in tombs dating from the LH IIIC, and from a tholos tomb in Traghana-Vighlitsa, Messenia, unfortunately from a secondary context (ibid., with bibliography; $c f$. Phillips 2008: 144).

As J. Phillips has noted, the frequency of occurrence for these pendants decreases as distance from Egypt increases, so it is not surprising that such elements are much rarer in the Central Mediterranean, at least for the time being. In fact, the only known examples were found in the necropolis of Piazza Monfalcone, in the Aeolian island of Lipari, dated from the Late Bronze Age 1-2 (Ausonio II horizon) (11 ${ }^{\text {th }}$ $-9^{\text {th }}$ century) (Matarese et al. 2015: 127-8).

This being said, several carnelian pendants clearly belonging to the type in question have been found further west, in the southern Iberian Peninsula (and also in Ibiza) (Fig. 2-4). The significance of these pieces was first highlighted with the publication of a special dossier coordinated by J. C. Martín de la Cruz (2004; also, Martín de la Cruz et al. 2005), in which examples from four sites were published.

These studies were set against the wider backdrop of research on the material evidence of contacts between the south of the Iberian Peninsula and the Eastern Mediterranean during the Bronze Age, stemming from the discovery of the Mycenaean pottery of Llanete de los Moros, Córdoba (Martín de la Cruz 1988; cf. Ruiz-Gálvez Priego 2009) and of several more examples of wheel-made pottery of unknown origin in Late Bronze Age contexts (Martín de la Cruz 2008, with bibliography). 


\begin{tabular}{|c|c|c|c|c|c|c|}
\hline$\#$ & Provenance & Context & Chronology (contextual) & Variant & Lenght & Width \\
\hline 1 & Sierra de San Cristóbal (Cádiz) & Domestic & LBA (10th - 9th cent.?) & stilisierte & $2,2 \mathrm{~cm}$ & $1 \mathrm{~cm}$ \\
\hline 2 & $\begin{array}{c}\text { Monte do Outeiro (Reguengos de } \\
\text { Monsaraz) }\end{array}$ & Domestic & LBA (9th - 8th cents.?) & naturgetraue & $1,6 \mathrm{~cm}$ & $0,9 \mathrm{~cm}$ \\
\hline 3 & $\begin{array}{l}\text { Los Castillejos de la Granjuela } \\
\text { (Córdoba) }\end{array}$ & Domestic? & NA & stilisierte & $1,75 \mathrm{~cm}$ & $0,95 \mathrm{~cm}$ \\
\hline 4 & Cabezo de Córdoba (Córdoba) & Domestic? & NA & stilisierte & $1,75 \mathrm{~cm}$ & $0,8 \mathrm{~cm}$ \\
\hline 5 & Villa Vieja (Málaga) & Domestic? & NA & stilisierte & $3 \mathrm{~cm}$ & NA \\
\hline 6 & Villa Vieja (Málaga) & Domestic? & NA & stilisierte & $2,7 \mathrm{~cm}$ & $1,4 \mathrm{~cm}$ \\
\hline 7 & Pocito Chico (Cádiz) & Domestic & $\begin{array}{l}\text { LBA - EIA transition (9th - 8th } \\
\text { cent.?) }\end{array}$ & stilisierte & $1,65 \mathrm{~cm}$ & $1 \mathrm{~cm}$ \\
\hline 8 & Mesas de Asta (Cádiz) & Domestic & $\begin{array}{l}\text { LBA - EIA transition (9th - 8th } \\
\text { cent.?) }\end{array}$ & NA & NA & NA \\
\hline 9 & Mesas de Asta (Cádiz) & Funerary & $\begin{array}{l}\text { LBA - EIA transition (9th - 8th } \\
\text { cent.?) }\end{array}$ & NA & NA & NA \\
\hline 10 & NA (Museo de Jérez) & NA & NA & NA & NA & NA \\
\hline 11 & Salsa 3 (Serpa) & Domestic & EIA (6th - 5th cents.) & naturgetraue & NA & NA \\
\hline 12 & Vinha das Caliças 4 (Beja) & Funerary & EIA (2nd half of the 6th cent.) & stilisierte & $1,5 \mathrm{~cm}$ & $0,8 \mathrm{~cm}$ \\
\hline 13 & Monte do Bolor 1-2 (Beja) & Funerary & EIA (6th cent.) & stilisierte & $2,4 \mathrm{~cm}$ & $1,1 \mathrm{~cm}$ \\
\hline 14 & Cabeço da Vaca (Alcoutim) & Funerary & EIA (6th - 5th cents.) & stilisierte & $1,2 \mathrm{~cm}$ & $0,75 \mathrm{~cm}$ \\
\hline 15 & Ébora (Cádiz) & Votive? & $\begin{array}{c}\text { EIA - LIA transition (late 6th - } \\
\text { early } 5 \text { th cents.) }\end{array}$ & stilisierte & $2,7 \mathrm{~cm}$ & $1,25 \mathrm{~cm}$ \\
\hline 16 & Puig des Molins (Ibiza) & Funerary & EIA (late 7th cent.) & stilisierte & $1,2 \mathrm{~cm}$ & $0,75 \mathrm{~cm}$ \\
\hline 17 & Mesas do Castelinho (Almodôvar) & Domestic & Roman (1st cent. CE) & stilisierte & $1,75 \mathrm{~cm}$ & $0,8 \mathrm{~cm}$ \\
\hline 18 & Torre d'Ares (Tavira) & Funerary & Roman (1st - 2nd cents. CE?) & stilisierte & $2,1 \mathrm{~cm}$ & $1 \mathrm{~cm}$ \\
\hline
\end{tabular}

Figure 2 - Inventory and basic characteristics of the phytomorphic carnelian pendants found in the Iberian Peninsula (NA = not available).

In fact, since the publication of the aforementioned examples, these carnelian pendants have become part and parcel of the discussion around the contested concept of "Precolonization" and the general dynamics of contact between the Iberian Peninsula and the Mediterranean during the late second and early first millennia, having received considerable attention in several contributions to a landmark volume on the subject (Torres Ortiz 2008: 77-8; López Castro 2008: 276; Martín de la Cruz 2008: 294-5; Escacena 2008: 312-4), as well as in more recent academic works (Gomá Rodríguez 2018: 211).

In the meanwhile, however, new finds, in Ibiza, Andalusia and especially in southern Portugal have considerably enlarged the corpus of known phytomorphic carnelian pendants in the Far West, while also widening their geographical and, quite significantly, their chronological distribution. In light of this fact, but also of the more detailed picture currently available for their diffusion in the Eastern Mediterranean, it seems appropriate to revisit these pendants and to reconsider their significance for the reconstruction of patterns of intercultural contact and trade during the Late Bronze and Early Iron Ages.

\section{Phytomorphic carnelian pendants in the Iberian Peninsula: distribution, chronology, and uses}

\subsection{The corpus: phytomorphic carnelian pendants in the Far West}

The studies included in the pioneering dossier mentioned above presented a total of four pendants, from Los Castillejos de la Granjuela (Córdoba) (Vera Rodríguez 2004; Martín de la Cruz et al. 2005), Cabezo de Córdoba (Córdoba) (Sánchez Romero \& Martín de la Cruz 2004), Sierra de San Cristóbal (Cádiz) (Ruiz Mata et al. 2004) and Pocito Chico (Cádiz) (Ruiz Gil \& López Amador 2004). All of these finds were tentatively attributed to the Late Bronze Age and set within the framework of 
Mediterranean contacts between the Iberian Peninsula and the Eastern Mediterranean still during the late $2^{\text {nd }}$ millennium (Martín de la Cruz 2004; Martín de la Cruz 2008: 295).

Since then, however, the number of known examples has grown exponentially, with new finds in both Andalusia (Torres Ortiz 2013; Marzoli et al. 2014: 173-6) and southern Portugal (Cardoso \& Gradim 2006: 213, figs. 156; Gonçalves et al. 2011; Mataloto 2012: fig. 23; Arruda et al. 2017: 209, fig. 6; Soares et al. 2017: 281 e fig. 11; Estrela 2019: 199-200, fig. 5 ; cf. Gomes 2018), elevating the total number of phytomorphic carnelian pendants in the Iberian Peninsula to 17, to which one example from Ibiza (Fernández \& Mezquida 2011: Fig. 2, n.3) can be added (Fig. 2).

The finds from southern Portugal are particularly significant, not only because they widen the geographic distribution of these pieces further into the Atlantic Far West, but especially due to the fact that they broaden the chronological framework for their distribution, as many of the Portuguese examples retrieved from well characterized contexts can be dated securely in the Early Iron Age ( $c f$. infra), forcing us to re-evaluate the chronological attribution of some of the earlier finds.

At the current state of research, the oldest example of this type of carnelian pendants in Iberia seems to be the piece from the settlement of Sierra de San Cristóbal, which is said to have been retrieved in a Late Bronze Age context (Ruiz Mata et al. 2004) (Fig. 3, n.1). The information currently available about this occupation suggests it predates the establishment of any intense contacts with the Phoenicians who would eventually settle in the nearby site of Castillo de Doña Blanca (Ruiz Mata \& Pérez 1995), as no wheel-made pottery was retrieved (Ruiz Mata et al. 2004: 11). The nature of the local, hand-made wares suggests the site dates to an advanced stage of the regional Late Bronze Age, well within the first millennium, and possibly as late as the $9^{\text {th }}$ century (Ruiz Mata \& Pérez 1995: 52).

Yet another occurrence which seems to date back to the Late Bronze Age has been documented in the Portuguese site of Monte do Outeiro 2 (Reguengos de Monsaraz) (Mataloto 2012: 207, fig. 23; see also Calado et al. 2007: 138-40) (Fig. 3, n.2). While the exact chronology of this small and open rural settlement has not been ascertained, it has been attributed to a horizon close to the end of the regional Bronze
Age (Mataloto 2012: 207) and could tentatively be considered roughly contemporary with the previous example.

Other pieces which have previously been attributed to the Late Bronze Age should be reconsidered in the light of the broader chronology of phytomorphic carnelian pendants currently documented both in the Levant and in the Iberian Peninsula ( $c f$. infra). Among these, the examples from the Córdoba province deserve special attention due to their historiographical significance.

The pendant from Los Castillejos de la Granjuela (Fig. 3, n.3), which received special attention in early studies on this type of pieces (Vera Rodríguez 2004; Martín de la Cruz et al. 2005), poses some interpretive difficulties. Not only is it a surface find, but the remaining material retrieved during surface surveys seems to relate exclusively to a very early occupation, dating to the Chalcolithic/ Early Bronze Age (Vera Rodríguez 1999: 710-20; 2004). Thus far the hypotheses put forward to explain the apparent chronological incongruence between the carnelian pendant and the remaining assemblage seem somewhat unsatisfactory.

On the one hand, it has been suggested that the apparent absence of later Bronze Age material could be the result of an archaizing tendency, in which material culture of Chalcolithic/ Early Bronze Age tradition endured until the later second millennium (Martín de la Cruz et al. 2005: 508). However, as the material culture of the regional Late Bronze Age becomes better known ( $c f$. Garrido Anguita 2017), this hypothesis seems increasingly unlikely.

Another suggestion, put forward by J. L. Escacena, entailed attributing the carnelian pendant to the early second millennium (Escacena 2008: 313-4). However, and while there certainly is significant evidence of the arrival of Mediterranean prestige goods to Iberia in Prehistory, it has already been pointed out that the specific type of carnelian pendant in question does not appear in Egypt itself before the mid- $2^{\text {nd }}$ millennium. There is furthermore no evidence for its distribution beyond the Nile Valley until the $14^{\text {th }}$ century, so an earlier chronology for any of the Iberian examples seems untenable.

In face of these considerations, and of the lack of stratigraphic data to reconstruct the occupation sequence of Los Castillejos, the chronology and cultural setting of the carnelian pendant found in this site cannot be ascer- 
tained with any degree of clarity, so its significance for the overall discussion of this class of adornment elements is only relative.

As for the piece from Cabezo de Córdoba (Sánchez Romero \& Martín de la Cruz 2004) (Fig. 3, n.4), also a surface find, it poses different problems. In fact, the remainder of the material assemblage retrieved in this site reveals a long period of occupation, from the Chalcolithic to the Roman Period (id.: 9, fig. 5).

A specific mention is made to examples of "Carambolo style" painted wares, the chronology of which is currently debated ( $c f$. Casado Ariza 2015) but which could either date from the Late Bronze Age or from the beginning of the Early Iron Age, as well as to (presumably Early Iron Age) grey wares and painted wares attributed to the Late Iron Age (Sánchez Romero \& Martín de la Cruz 2004). Given the broad chronology of the surface material assemblage retrieved in this site, the specific chronology of the pendant cannot be established with certainty.

The more recent finds from the settlement of Villa Vieja (Málaga) (Marzoli et al. 2014: 173-6, Abb. 5) (Fig. 3, nn.5-6) pose a similar challenge. This site, which has yielded two further carnelian pendants of the type discussed here, is also known from surface surveys only. During these surveys, remains of two distinct periods of occupation have been identified: the first has been dated to the Late Bronze Age, perhaps to an advanced moment within that period; the site then seems to be reoccupied from the $7^{\text {th }} / 6^{\text {th }}$ century on (Suárez Padilla 2018: 8490), after a perceived hiatus corresponding to the beginning of the Iron Age.

Based on the previously known parallels, the carnelian pendants from Villa Vieja have been associated with the earlier occupation of the site (Marzoli et al. 2014: 173; Suárez Padilla 2018: 90). This is a plausible hypothesis, since, as commented above, examples are known in southern Iberia dating to the Late Bronze Age. However, with the current available data, the hypothesis that these pendants belong to the later phase of the site cannot be dismissed either ( $c f$. infra). In the absence of contextual coordinates for these pieces, their specific chronology cannot therefore be clearly established.

The pendant from Pocito Chico (Ruiz Gil \& López Amador 2004) (Fig. 3, n.7) offers a somewhat clearer picture. In fact, and while a very early date for the Late Bronze Age hut documented in this site, and specifically for the pendant retrieved therewithin, has on occasion been suggested (Ruiz Gil \& López Amador 2001: 155), the general consensus is that this structure dates from a transitional phase between the Late Bronze and the Early Iron Ages, or from an early stage of the latter, possibly dating from the late $9^{\text {th }}$ or the early $8^{\text {th }}$ century ( $c f$. Torres Ortiz 2008: 77-8; Gomá Rodríguez 2018: 211).

Two other pendants retrieved in Mesas de Asta, also in Cádiz, have not yet been fully published (Torres 2013). According to M. Torres Ortiz (2013: 2), one of these pieces was retrieved in the settlement during the 1942 excavation campaign ( $c f$. Esteve Guerrero 1945) while the other was recovered during intensive survey work in the associated necropolis ( $c f$. González Rodríguez et al. 1995: 217-20). Both appear to belong to a chronological and cultural horizon similar to that of the piece from Pocito Chico (Torres Ortiz 2013; cf. Gomá Rodríguez 2018: 211). The Archaeological Museum of Jérez de la Frontera also houses a third piece of the same type, unfortunately of unknown provenance (Torres Ortiz 2013: 2).

On the subject of phytomorphic carnelian pendants attributed to the Late Bronze Age, a final note must be added with regard to the Portuguese example from Salsa 3 (Serpa) (Gonçalves et al. 2011). In a previous work (Gomes 2018: 61) this piece was mistakenly associated with the Late Bronze Age occupation of the site ( $c f$. Deus et al. 2009). More recently, however, it has been confirmed that the context in which the pendant was found dates in fact from the $6^{\text {th }}-5^{\text {th }}$ centuries (Estrela 2019: 200; cf. Antunes et al. 2017: 171-3), and can thus be related to the later, Early Iron Age occupation of the same area (cf. Antunes et al. 2017: 171-5). This piece is therefore contemporary with several others which have recently come to light in the region ( $c f$. infra). 


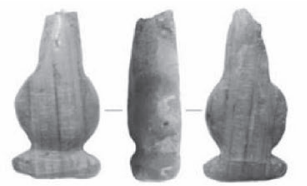

1

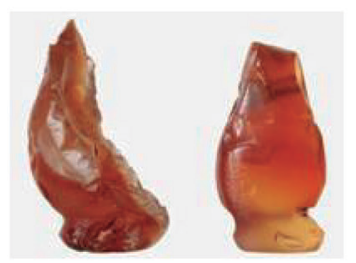

5-6

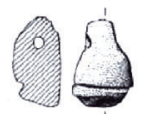

10

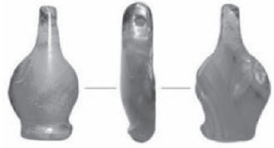

3

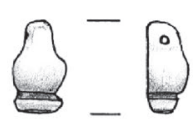

12

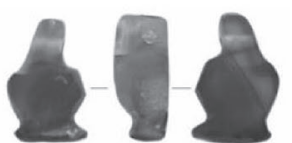

7
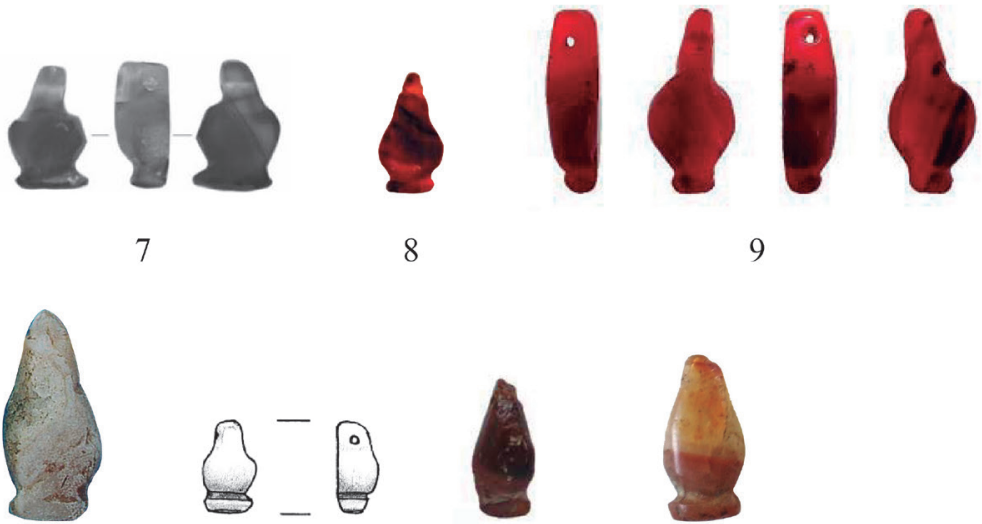

11
8
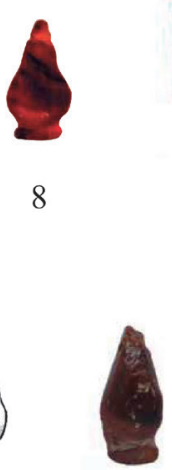

13
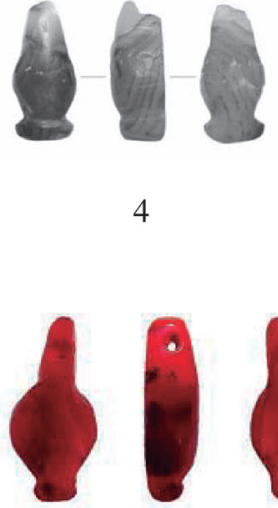

4

9

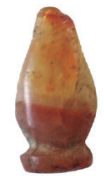

14

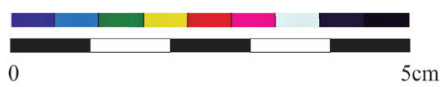

Figure 3 - Phytomorphic carnelian pendants found in the Iberian Peninsula: 1. Sierra de San Cristóbal (after Martín de la Cruz 2004); 2. Monte do Outeiro (after Mataloto 2012, adapted); 3. Los Castillejos de la Granjuela and 4. Cabezo de Córdoba (after Martín de la Cruz 2004); 5-6. Villa Vieja (after Marzoli et al. 2014); 7. Pocito Chico (after Martín de la Cruz 2004); 8. Vinha das Caliças 4 (after Arruda et al. 2017); 9. Monte do Bolor 1-2 (after Soares et al. 2017); 10. Cabeço da Vaca (after Cardoso \& Gradim 2006); 11. Tesoro de Ébora (after Mata Carriazo 1973); 12. Puig des Molins (after Fernández \& Mezquida 2011); 13. Mesas do Castelinho (after Estrela 2019); 14. Torre d'Ares (photo by C. Pereira, kindly provided by the author).

The development of archaeological research in southern Portugal in the past few years, fuelled by the major preventive work surrounding the construction of the Alqueva dam and its associated irrigation system, has in fact resulted in the identification of several other examples of carnelian pendants of the type discussed here. These works were namely responsible for the find of two other phytomorphic pendants, in this case retrieved in the Early Iron Age necropolis of Vinha das Caliças 4 (Arruda et al. 2017: 209, fig. 6; cf. Gomes 2014: fig. 3) (Fig. 3, n.8) and Monte do Bolor 1-2 (Soares et al. 2017: 281 e fig. 11) (Fig. 3, n.9), both in Beja.
In the former site the pendant in question was retrieved in Tomb 48, which housed a rich female burial; this well-preserved context can be securely dated to the second half of the $6^{\text {th }}$ century (Arruda et al. 2017). As for the pendant from the latter site, it was found in Tomb UE 5638, which contained the disturbed burial of an adult individual (Soares et al. 2017: 2801). The necropolis of Monte do Bolor 1-2 can also be dated in the $6^{\text {th }}$ century (id.: 292).

To these two examples from inner Alentejo can also be added a somewhat less clear find from the Early Iron Age necropolis of $\mathrm{Ca}$ beço da Vaca (Alcoutim) (Cardoso \& Gradim 2006). From Tomb 1 of this cist necropolis in the Eastern Algarve region comes in fact a 
carnelian pendant (Fig. 3, n.10) whose general features are clearly reminiscent of the type under discussion, although its proportions and workmanship seem much less accomplished than those of the remaining examples listed above (id.: 213, figs. 15-6). Whether this is a lower quality product, or even perhaps a broken and locally "repaired" or refashioned piece of the type in question, this specimen can nonetheless be tentatively included in the list of phytomorphic carnelian pendants.

While some finds in the necropolis, namely a few ceramic vessels, seem to point to an older, Early/ Middle Bronze Age occupation of the site (Cardoso \& Gradim 2006: 221), there is little doubt that the necropolis of Cabeço da Vaca 1 can be globally dated to the $6^{\text {th }}-5^{\text {th }}$ centuries (id: 222) and that the carnelian piece relates to this later, Iron Age occupation. The piece under discussion could therefore be considered roughly contemporary with its counterparts from Vinha das Caliças 4 and Monte do Bolor 1-2.

On the other hand, it must me mentioned that these new Portuguese finds shed a new light on another pendant which has long been known but remained more or less isolated until now. Known since the 1970s, the carnelian pendant from the Ébora Treasure (Cádiz) (Mata Carriazo 1970: Lám. I; 1973: 354-5, figs. 2612) (Fig. 3, n.11), which in light of the associated jewellery assemblage can be dated to the late $6^{\text {th }}-$ early $5^{\text {th }}$ centuries ( $c f$. Nicolini 1991: 214-25; Torres Ortiz 2002: 239-41; 2008: 78), can now be usefully confronted with the examples from southern Portugal, thus representing a further indication of the long period of use of this type of adornment elements.

While not strictly hailing from the Iberian Peninsula, another example found in the necropolis of Puig des Molins in Ibiza (Fernández \& Mezquida 2010: Fig. 2, n.3) (Fig. 3, n.12) must also be mentioned here. This piece was part of an archaic burial dated to the late $7^{\text {th }}$ century $(i d$.$) which also contained an Egyp-$ tian-type scarab (id.: Fig. 2, n.5). Together with the material from southwestern Iberia mentioned above, this piece confirms that these pendants kept circulating well into the $1^{\text {st }}$ millennium, while highlighting the role of Phoenician trade in their diffusion during this period.

To close this overview of the Iberian phytomorphic carnelian pendants, a mention must be made here to two further Portuguese finds.
These two pieces undoubtedly fit into the type discussed in this contribution, but were found in much later, Roman contexts, thus posing significant but very interesting problems of their own.

The first comes from the settlement of Mesas do Castelinho (Almodôvar), in inner Alentejo, a site occupied from the Late Iron Age until well into the Early Roman Empire (cf. Estrela 2010). The pendant in question (Estrela 2019: 199-200, fig. 5) (Fig. 3, n.13) was itself retrieved in a context dated to the first half of the $1^{\text {st }}$ century CE (id.: 199).

The presence of this pendant in such a late context could be interpreted in different ways. It would not be farfetched, for instance, to think that this piece is in fact in a secondary context, having originally come from deposits dating to the earliest phases of the settlement disturbed during the Roman period. This could make it only slightly later than the Early Iron Age examples mentioned above.

On the other hand, it is tempting to consider the alternative view that this piece may have been an heirloom ( $c f$. Lillios 1999) or a keimêlia (cf. Reiterman 2016), preserved and transmitted through several generations until it was finally lost or abandoned in the Roman period; however, and while possible, this hypothesis remains entirely speculative.

Finally, as S. Estrela has rightly pointed out, the find from Mesas do Castelinho sheds new light on a much older discovery, namely that of yet another phytomorphic carnelian pendant retrieved in the area of Torre d'Ares (Tavira) in the $19^{\text {th }}$ century by S. Estácio da Veiga (1891: 260, Est. XXVIII, n.10) (Fig. 3, n.14). This piece has recently been republished (Pereira 2018: 196, fig. 81, n. 4) as part of an in-depth study of the finds from this area, which can now confidently be identified as part of the northern necropolis of the roman city of Balsa (id.: 96-257), used between the $1^{\text {st }}$ and the $5^{\text {th }}$ centuries CE but especially during the $1^{\text {st }}-2^{\text {nd }}$ centuries CE (Pereira 2018: Quadro 1).

Given the concomitant testimonies of these two pieces, which could be roughly contemporary, the hypothesis put forward by S. Estrela (2019: 200) that these pendants actually date from the Roman period cannot be readily dismissed either. This being said, one important argument against this very late dating for these pendants is the apparent absence of parallels for their production and use anywhere else beyond the Iron Age. 
While this could change with new finds or further research, this fact, such as it is, seems to weigh the balance towards other, more complex, and perhaps more interesting explanations, either related to the transmission through time of valued heirlooms or keimêlia (cf. supra) or, alternatively, to the retrieval and social valorisation of archaica dispersed through the landscape.

\subsection{The chronology, distribution, and uses of phytomorphic carnelian pendants in Iberia: Comments on the corpus}

As can be gauged from the inventory presented in the previous pages, the corpus of phytomorphic carnelian pendants in the Iberian Peninsula as it stands today reveals a somewhat more complex panorama than that which was previously available. Three major aspects can be highlighted with regard to that panorama, namely the somewhat different chronological setting to which these pieces can now be attributed, their much wider geographical distribution, and the emergence of significant trends with regard to the functional nature of their find contexts.

With regard to the first aspect, it is worth noting that, at the current stage of our knowledge, there is little internal evidence to support a high chronology for the carnelian pendants so far documented in the Iberian Peninsula. While external parallels did lend credence to the idea that these pieces arrived in the Far West through Mycenaean, Sub-Mycenaean or Cypriote trade routes and contacts during the late $2^{\text {nd }}$ millennium (Martín de la Cruz 2004; 2008: 295; Martín de la Cruz et al. 2005: 508), their find contexts do not seem to support this view.

In fact, as commented above, the earlier examples so far documented can indeed be attributed to the Late Bronze Age (Sierra de San Cristóbal, Monte do Outeiro) but, apparently, to a late stage of that period, in the early $1^{\text {st }}$ millennium, perhaps shortly predating the establishment of permanent Phoenician settlements. Still other examples can actually be dated to a Late Bronze/ Early Iron Age transitional phase or to the beginning of the "Orientalizing" period (Pocito Chico, Mesas de Asta), being associated with the first material evidence of direct Phoenician trade and influence.

Very significantly, however, recent finds in Ibiza (Puig des Molins) and especially Portugal (Vinha das Caliças 4, Monte do Bolor 1-2,
Salsa 3, Cabeço da Vaca) have consistently demonstrated that, whether in continuity with the earlier finds or as part of a "revival" in popularity, these pendants were still circulating and being used between the $7^{\text {th }}$ and the $6^{\text {th }}$, or perhaps the $5^{\text {th }}$ centuries, thus offering a new context for older finds dating within the same chronological bracket (Ébora Treasure).

While it is entirely possible that these later examples are in fact prized possessions, which have been transmitted through several generations, thus having considerably long periods of use which could stem back to the Late Bronze Age (Marzoli et al. 2014: 178; Suárez Padilla 2018: 90), it should once again be noted that no such explanatory framework is strictly necessary in this case. In fact, and while the distribution of phytomorphic carnelian pendants throughout the Mediterranean in the first millennium remains poorly known (however, cf. Fernández \& Mezquida 2011), their presence in significant quantities in Egypt itself (Phillips 2003: 457) and especially in the Levant (Golani 2013: 165-6) until at least the $7^{\text {th }}$ century is well attested and could be directly linked to the arrival of these pieces in the West through Phoenician trade.

This being said, the presence of two such pendants in Roman contexts in the Portuguese territory (Mesas do Castelinho, Torre d'Ares) is harder to explain with the data currently available and could in fact point towards an interpretation as heirlooms, keimêlia or archa$i c a$, much older in date but either preserved or retrieved at this later time.

Finally, it must be stressed that the widening chronological span of these pendants now raises some reservations regarding the specific date and cultural setting of some of the known examples found on the surface of multi-phase sites (Cabezo de Córdoba, Villa Vieja, and possibly Los Castillejos de la Granjuela), as prudence recommends that these pieces no longer be automatically ascribed to older, Late Bronze Age horizons, rather than later, Iron Age ones.

Regarding the second significant aspect of this corpus, that of geographical distribution (Fig. 4), the inventory presented here reinforces some of the trends already noted in previous works, namely the key role of the Bay of Cádiz and its hinterland as a possible reception and redistribution centre for these pendants, which is not surprising due to the importance of the Phoenician settlements in the area (Ruiz Mata 
\& Pérez Pérez 1995; Botto 2014), and the significance of the Guadalquivir River as a path- way for their diffusion further inland, into the Córdoba region.

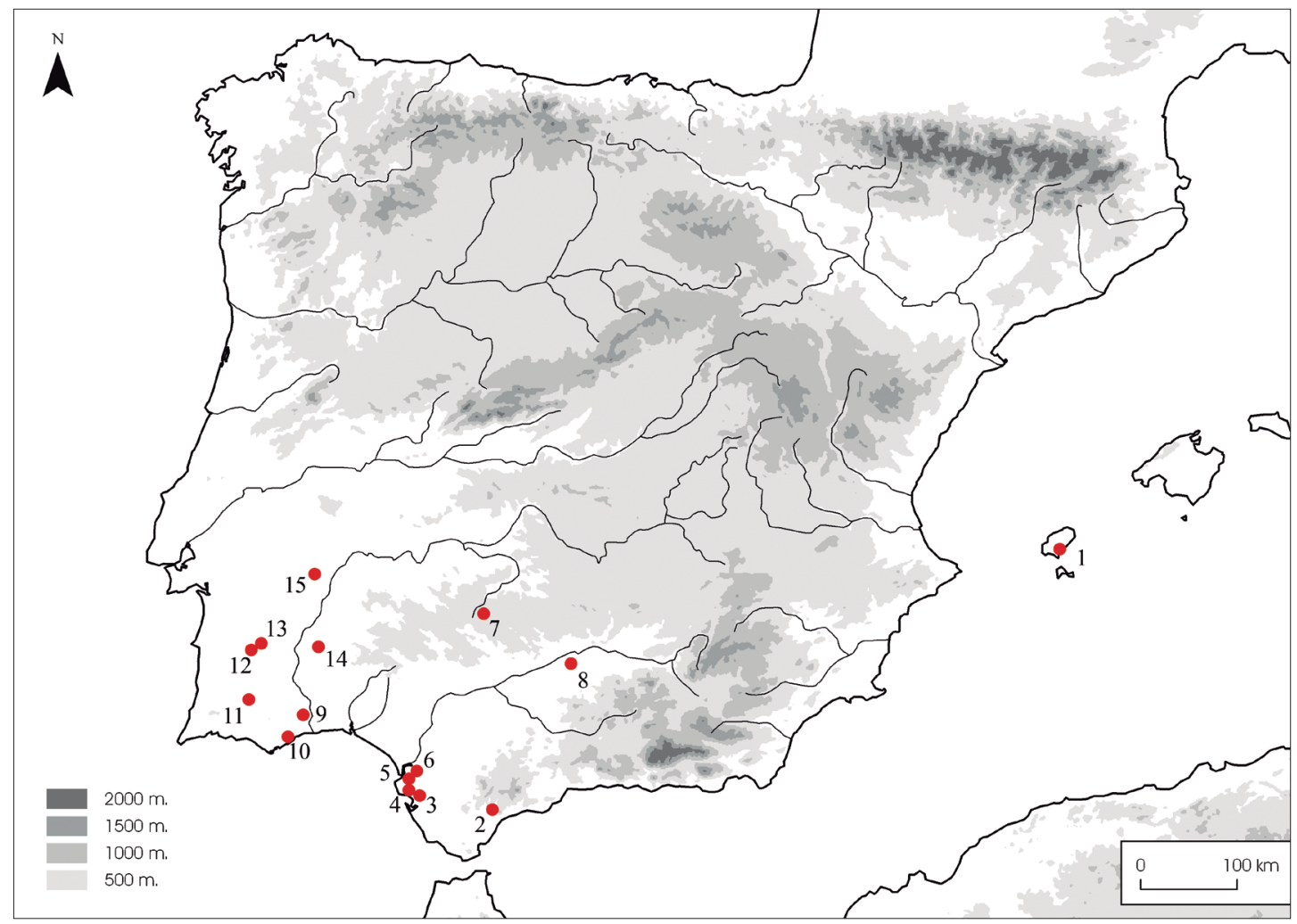

Figure 4 - Distribution of phytomorphic carnelian pendants in the Iberian Peninsula: 1. Puig des Molins; 2. Villa Vieja; 3. Sierra de San Cristóbal; 4. Pocito Chico; 5. Mesas de Asta; 6. Ébora; 7. Los Castillejos de la Granjuela; 8. Cabezo de Córdoba; 9. Cabeço da Vaca; 10. Torre d'Ares; 11. Mesas do Castelinho; 12. Vinha das Caliças 4; 13. Monte do Bolor 1-2; 14. Salsa 3; 15. Monte do Outeiro. Cartographic base: Trabajos de Prehistoria - CSIC.

More recent finds have however signalled new axes of distribution, both to the East, through the Guadiaro River and in close relation to the well-known Phoenician settlements of the Málaga coast (cf. Marzoli et al. 2014), and to the West, where the Guadiana River has emerged as a major pathway allowing the diffusion of these pendants to the inner Alentejo area, apparently from the Late Bronze Age to a late stage of the Early Iron Age ( $c f$. Gomes 2018), if not beyond.

Again, this fact cannot be dissociated from the significant and potentially early Phoenician presence which has been detected in the lower valley of this river (Berrocal-Rangel \& Silva 2010; Pérez Macías et al. 2017; Marzoli \& García Teyssandier 2019) and the significance of the "Orientalizing" settlement of Castro Marim, which controlled the access to this wa- terway (Arruda 1999-2000: 36-53; Arruda et al. 2007).

Finally, with regard to the nature of the context finds of these pieces, it should be pointed out that a clear differentiation exists between the older finds and the more recent ones. In fact, and while four out of the five pendants dating from the Late Bronze Age and the earliest horizons of the Iron Age (i.e., 80\%) come from settlements, with only one example $(20 \%)$ from Mesas de Asta suggesting an early incorporation into funerary inventories, four out of the six pendants dated to the $7^{\text {th }}-5^{\text {th }}$ centuries $(66,6 \%)$ come from funerary contexts, while another $(16,7 \%)$ comes from a jewellery deposit and only one example $(16,7 \%)$ hails from a settlement. The examples retrieved in Roman contexts are equally divided between a settlement and a necropolis. 
This trend highlights the growing significance of funerary spaces as scenarios for the representation of power, status, and social identities ( $c f$. Torres Ortiz 1999; Gomes 2016), which entailed an increasing concentration of wealth in tombs. This is particularly visible in the Early Iron Age rural necropolis of southern Portugal ( $c f$. Gomes 2014; 2016; contributions in Jiménez Ávila 2017), where several of the pendants discussed above have been found, along numerous other exotic and prestigious materials.

One final note on the corpus regards the archaeometric analyses that have been undertaken on several of the pendants listed above. The pendants from Los Castillejos de la Granjuela, Cabezo de Córdoba, Sierra de San Cristóbal and Pocito Chico (Barrios Neira et al. 2004), as well as those from Salsa 3 (Gonçalves et al. 2011) and Villa Vieja (Marzoli et al. 2014: 1789), have been analysed using various methods, but especially X-Ray Diffraction, the results of which seem to show a high degree of uniformity as far as major components are concerned, with only minor variations, the significance of which is unclear. Their compositional profiles are furthermore similar to those from the carnelian beads from La Fonteta and Peña Negra (Alicante) (Martínez Mira \& Vilaplana Ortego 2014).

Unfortunately, the lack of comparable analytical work for other Egyptian, Near Eastern and Mediterranean pieces and for the known sources of raw materials precludes any further comparisons and therefore interpretations of the Iberian results.

\section{The significance of carnelian pendants in Iberian Protohistory: some concluding remarks}

The corpus and the discussion presented in the previous pages, which complement and update the valuable works that first highlighted the importance of these phytomorphic carnelian pendants (Martín de la Cruz 2004; Martín de la Cruz et al. 2005), show a very different panorama which results directly from the development of research, but also from the stimulus introduced by those works to study a previously overlooked type of object.

The advances produced in the past fifteen years have considerably altered our understanding of the chronological and cultural set- ting of these pendants, which can no longer be clearly associated with very early contacts between the Iberian Peninsula and the Eastern Mediterranean dated to the $2^{\text {nd }}$ millennium (cf. Torres Ortiz 2008: 77-8; Gomá Rodríguez 2018: 211). In fact, and although an early arrival for some of these adornments cannot be excluded in light of Mediterranean evidence, it now seems increasingly likely that these pieces, as many other exotic and prestigious goods, were first introduced in Iberia through Phoenician trade.

This is consistent with both external and internal evidence. Regarding the latter, the chronology of the Iberian finds clearly falls within the timespan of Phoenician presence and trade, beginning perhaps during a period of restricted presence ( $c f$. Torres Ortiz 2008: 82-5) and extending at least until the restructuring of the Phoenician trading and settlement network in the $6^{\text {th }}$ century (Martín Ruiz 2007). On the other hand, the presence of one such piece in the necropolis of Puig des Molins (Fernández \& Mezquida 2011) could be seen as a strong indicator of a Phoenician role in the distribution of these pieces.

As for the former, the use of phytomorphic carnelian pendants during the $1^{\text {st }}$ millennium in Egypt and especially in the Levant has become more and more significant in the past few decades (Phillips 2003: 457; Golani 2013: 165-6), making it perfectly plausible for them to be incorporated into the array of trade goods carried by the Phoenicians to the west.

Two components of that array offer a particularly useful context for the phytomorphic carnelian pendants discussed here. Naturally, one is the wide assortment of aegyptiaca introduced through Phoenician trade networks in the Far West (Padró 1980-5; 1995; García Martínez 2002; Almagro-Gorbea \& Torres Ortiz 2009; Almagro-Gorbea et al. 2009; Almagro-Gorbea \& Graells 2011), among which other carnelian objects can be mentioned, namely scarabs (Almagro-Gorbea et al. 2009: 86; Almagro-Gorbea \& Graells 2011). This class of material could offer a background for the arrival of the Egyptian(-type) pendants discussed here.

The second significant component which should be taken into consideration comprises other carnelian objects, particularly beads, which arrive in the Iberian Peninsula in significant numbers since the Late Bronze Age (Lorrio 2008: 290-1; Martínez Mira \& Vilaplana 
Ortego 2014: 864-5; Gomes 2018: 59-60, with bibliography).

One possible early example is a cylindrical bead which formed part of a necklace found in the $19^{\text {th }}$ century in Almuñécar (Rodríguez de Berlanga 1891: 334). J. C. Martín de la Cruz has suggested this necklace could be dated in the late $2^{\text {nd }}$ millennium (Martín de la Cruz 2008: 292); there is however little clear evidence to support such an early chronology for this material, which has also been dated by other authors to the Iron Age (Blanco Freijeiro 1962).

Leaving aside this problematic example, it seems nonetheless clear that some carnelian beads did arrive in the Iberian Peninsula still during the late $2^{\text {nd }}$ millennium ( $c f$. Gomes 2018). However, it has been noted that the number of documented carnelian beads seems to increase towards the end of that period (id.: 68; $c f$. Lorrio 2008: 291; Gomá Rodríguez 2018: 210-1), that is to say at the time when phytomorphic carnelian pendants make their appearance.

Again, this would fall within a chronological horizon compatible with the beginnings of the Phoenician presence and trade in the Far West. Furthermore, significant adornment elements in carnelian have been found in key Phoenician - and later Punic - sites and areas throughout the Mediterranean, from Akhziv (Mazar 2004: 92-3) to North Africa, namely Carthage (Quillard 1979: 110) and Utica (Arveiller-Dulong \& Nenna 2011: 128-31), Sicily (Giammellaro 2008: nn.103, 106, 108, 132, 140), Sardinia (Harden 1962: fig. 103) and Ibiza (Vives y Escudero 1917: 77; Fernández \& Padró 1982; cf. supra).
Carnelian beads are also well documented in several Phoenician and Punic sites in the Iberian Peninsula itself, including the necropolis of Gadir (Cádiz) (Perdigones et al. 1990: 414), Trayamar (Málaga) (Schubart \& Niemeyer 1976: 233), Cortijo de las Sombras (Málaga) (Arribas \& Wilkins 1969: 228), Puente de Noy (Molina Fajardo et al. 1982: 76) and Villaricos (Almería) (Astruc 1951: 34). The examples from the shipwreck of El Sec (Mallorca) (Arribas et al. 1987: 593) show that carnelian beads were still being transported by Punic merchants as late as the $4^{\text {th }}$ century, perhaps as trade products themselves.

Many more examples from "orientalizing" sites closely connected with the Phoenician trade network could be mentioned here ( $c f$. Gomes 2018), but the point is that the phytomorphic pendants presented above are far from isolated occurrences, and are well contextualized as part of an intense flow of exotic and prestigious elements to the Far West which feeds the constant demand of local communities, and particularly their elites, for distinctive elements which become firmly embedded in local representation practices and political economies.

Therefore, and with the abundant new data which has come to light in the past few years, the pendants discussed in this contribution can now be repositioned in the long and complex history of the interconnection between the southern Iberian Peninsula and the Mediterranean, and be analysed in a new light, as a significant component of the trade of exotic and prestigious materials - among which many Egyptian(-type) elements- set in motion in the early $1^{\text {st }}$ millennium by Phoenician merchants, and later settlers, in the Far West.

\section{Bibliography}

Alarashi, H. (2016): Butterfly Beads in the Neolithic Near East: Evolution, Technology and Socio-cultural implications. Cambridge Archaeological Journal, 26(3): 493-512. DOI: https://doi.org/10.1017/ S0959774316000342

Almagro-Gorbea, M.; Arroyo, A.; Corbí, J. F. M.; Marín, B.; Torres, M. (2009): Los escarabeos de Extremadura: una lectura socioideológica. Zephyrus, 63: 71-104.

Almagro-Gorbea, M.; Graells, R. (2011): Escarabeos del noreste de Hispania y del sur de la Galia: catálogo, nuevos ejemplares e interpretaciones. Lucentum, 30: 25-87. DOI: https://doi.org/10.14198/LVCENTVM2011.30.02

Almagro-Gorbea, M.; Torres Ortiz, M. (2009): Los escarabeos fenicios de Portugal. Un estado de la cuestión. Estudos Arqueológicos de Oeiras, 17: 521-54.

Antunes, A. S.; Deus, M. de; Estrela, S.; Larrazabal, J.; Soares, A. M. M.; Salvador Mateos, R. M. (2017): Monte do Bolor 3, Monte do Pombal 2, Salsa 3 e Torre Velha 3. Contextos de Planície da I Idade do Ferro do Alentejo Interior. In Jiménez Ávila 2017: 159-85. 
Arribas, A.; Trías, G.; Cerdà, D.; de Hoz, J. (1987): El Barco de El Sec (Calvià, Mallorca). Estudio de los materiales. Calvià, Ajuntament.

Arribas, A.; Wilkins, J. (1969): La necrópolis fenicia del Cortijo de las Sombras (Frigiliana, Málaga). Pyrenae, 5: 185-244.

Arruda, A. M. (1999-2000): Los Fenicios en Portugal. Fenicios y mundo indígena en el centro y sur de Portugal (siglos VIII-VI a.C.). Barcelona, Universidad Pompeu Fabra.

Arruda, A. M.; Barbosa, R.; Gomes, F. B.; Sousa, E. de (2017): A necrópole da Vinha das Caliças (Beja, Portugal). In Jiménez Ávila 2017: 187-225.

Arruda, A. M.; Freitas, V. T. de; Oliveira, C. F. (2007): Os Fenícios e a urbanização no Extremo Ocidente: o caso de Castro Marim. Las ciudades fenício-púnicas en el Mediterráneo Occidental (J. L. López Castro, ed.), Madrid, CEFYP: 459-82.

Arveiller-Dulong, V.; Nenna, M. D. (2011): Les verres antiques du musée du Louvre, 3. Parures, instruments et éléments d'incrustation. Paris, Louvre.

Astruc, M. (1951): La necrópolis de Villaricos. Madrid, Ministerio de Educación Nacional.

Aufrère, S. (1991): L'univers minéral dans la pensée égyptienne. Cairo, IFAO.

Barrios Neira, J.; Montealegre Contreras, L.; Martín de la Cruz, J. C.; Ibarra de Dios, F. J. (2004): Análisis de microscopía y difracción de RX sobre colgantes y cuentas. In Martín de la Cruz 2004: 14-6.

Beck, H. C. (1928): Classification and nomenclature of beads and pendants. Archaeologia, 77: 1-76.

Ben Basat, H. (2011): Early Iron Age beads at Tel Dor: a comparative study. MA Thesis, University of Haifa.

Berrocal-Rangel, L.; Silva, A. C. (2010): O Castro dos Ratinhos (Barragem do Alqueva, Moura). Lisbon, Museu Nacional de Arqueologia.

Blanco Freijeiro, A. (1962): Notas de Arqueología andaluza. Zephyrus, 11: 151-63.

Botto, M. (ed.) (2014): Los Fenicios en la Bahía de Cádiz. Nuevas investigaciones. Rome: Fabrizio Serra.

Brunet, O. (2009): Bronze and Iron Age carnelian bead production in the UAE and Armenia: new perspectives. Proceedings of the Seminar for Arabian Studies, 39: 57-68.

Calado, M.; Mataloto, R.; Rocha, A. (2007): Povoamento Proto-Histórico na Margem Direita do Regolfo do Alqueva (Alentejo, Portugal). Arqueología de la Tierra. Paisajes rurales de la protohistoria peninsular (A. Rodríguez Díaz \& I. Pavón Soldevila, eds.), Cáceres, Universidad de Extremadura: 129-79.

Cardoso, J. L.; Gradim, A. (2006): A Necrópole da Idade do Ferro de Cabeço da Vaca (Alcoutim). Xelb, 6: 203-26.

Casado Ariza, M. (2017): La cerámica con decoración geométrica del Carambolo. Seville, Universidad de Sevilla.

Caubet, A.; Yon, M. (2006): Quelques perles de cornaline. "I Will Speak the Riddle of Ancient Times». Archaeological and Historical Studies in Honor of Amihai Mazar (A. M. Maeir \& P. de Miroschedji, eds.), Warsaw, Eisenbrauns: 137-47.

Debrabant, F. (2016): La cornaline dans le Proche-Orient ancien. Origines, reseaux d'échanges, mise en forme et fonction sociale. PhD Thesis, Panthéon Sorbonne University.

Deus, M. de; Antunes, A. S.; Soares, A. M. M. (2009): A Salsa 3 (Serpa) no contexto dos povoados abertos do Bronze Final do Sudoeste. IV Encuentro de Arqueología del Suroeste Peninsular, Huelva, Universidad de Huelva: 514-43.

Escacena, J. L. (2008): Cantos de sirena: la precolonización fenicia de Tartesos. Contacto cultural entre el Mediterráneo y el Atlántico (siglos XII-VIII ane). La precolonización a debate (S. Celestino, N. Rafel \& X. L. Armada, eds.), Madrid, CSIC: 301-22.

Esteve Guerrero, M. (1945): Excavaciones de Asta Regia (Mesas de Asta, Jerez): campaña de 1945-46. Madrid, Ministerio de Educación.

Estrela, S. (2010): Os níveis fundacionais da Idade do Ferro de Mesas do Castelinho (Almodôvar): os contextos arqueológicos na (re) construção do povoado. MA Thesis, University of Lisbon.

Estrela, S. (2019): Adornos, espaço e tempo: as contas de colar em Mesas do Castelinho (Santa Clara-aNova, Almodôvar). Setúbal Arqueológica, 18: 193-214.

Fernández, J. H.; Padró, J. (1982): Escarabeos del Museo Arqueologico de Ibiza. Ibiza, Museo Arqueológico de Ibiza.

Fernández, J. H.; Mezquida, A. (2011): Una incineración excepcional arcaica en urna lítica de la necrópolis del Puig des Molins. Mainake, XXXII(I): 499-523. 
García Martínez, M. A. (2002): Documentos prerromanos de tipo egipcio de la vertiente atlántica hispano-mauritana. Montpellier: Paul Valéry University.

Garrido Anguita, J. M. (2017): El Sur de la Península Ibérica y el Mediterráneo Occidental: relaciones culturales en la segunda mitad del II milenio a.C.. Oxford, Archaeopress.

Giammelaro, A. S. (2008): I Vetri della Sicilia Punica. Rome, Bonpiani.

Golani, A. (2004): Jewelry. Bronze and Iron Age Tombs at Tell Beit Mirsim (S. Ben-Arieh, ed.), Jerusalem, Israel Antiquities Authority: 189-202.

Golani, A. (2009): Metallic and Non-Metallic Jewelry. Excavations at Tel Beth-Shean

1989-1996, III (N. Panitz-Cohen \& A. Mazar, eds.), Jerusalem, The Israel Exploration Society: 612-33.

Golani, A. (2013): Jewelry from the Iron Age II Levant. Fribourg: Academic Press.

Golani, A. (2014): Metallic and Nonmetallic Jewelry Objects. The Smithsonian Institution Excavation at Tell Jemmeh, Israel, 1970-1990 (D. Ben-Shlomo, G. W. Van Beek, eds.), Washington, Smithsonian Institute: 889-916.

Golani, A. (2016): The Jewelry from Iron Age I Contexts. Tel Miqne-Ekron Excavations, 9/1 (T. Dothan, Y. Garfinkel \& S. Gitin, eds.), Winona Lake, Eisenbrauns: 479-98.

Golani, A. \& Ben Shlomo, D. (2005): The jewelry. Ashdod VI. The Excavations of Areas H and K (19681969) (M. Dothan \& D. Ben Shlomo, eds.), Jerusalem, Israel Antiquities Authority: 247-64.

Goldman, H. (1956): Excavations at Gözlü Kule, Tarsus: From the Neolithic through the Bronze Age. Princeton, Princeton University Press.

Gomá Rodríguez, J. L. (2018): El bronce final y la protocolonización en la Península Ibérica. PhD Thesis, Complutense University of Madrid.

Gomes, F. B. (2014): Importações mediterrâneas em contextos «Pós-Orientalizantes» do Sul de Portugal (séculos VI-IV a.n.e.). Onoba, 2: 27-44.

Gomes, F. B. (2016): Contactos culturais e discursos identitários na I Idade do Ferro do Sul de Portugal (séculos VIII a V a.n.e.): leituras a partir do registo funerário. $\mathrm{PhD}$ Thesis, University of Lisbon.

Gomes, F. B. (2018): La Cornalina en el Bronce Final y la Edad del Hierro del Sur de Portugal. Lucentum, XXXVII: 55-74. DOI: http://dx.doi.org/10.14198/LVCENTVM2018.37.03

Gonçalves, A. P.; Soares, A. M. (2010): As «contas de colar» dos Ratinhos - I. As contas em pedra, análise por Difracção de Raios X. In Berrocal-Rangel \& Silva 2010: 389-92.

Gonçalves, A. P.; Soares, A. M.; Silva, A. C.; Berrocal-Rangel, L. (2011): Stone Beads from Late Bronze Age and Early Iron Age Settlements from South-Western Portugal: Analyses by X-Ray Diffraction. Proceedings of the 37th International Symposium on Archaeometry (I. Turbanti-Memmi, ed.), Berlin, Springer: 227-31. DOI: https://doi.org/10.1007/978-3-642-14678-7_32

González Rodríguez, R.; Barrionuevo Contreras, F.; Aguilar Moya, L. (1995): Mesas de Asta, un centro indígena tartésico en los esteros del Guadiana. Tartessos 25 años después, 1968-1993, Jérez de la Frontera, Ayuntamiento: 215-38.

Groman-Yaroslavski, I.; Bar-Yosef, D. (2015): Lapidary technology revealed by functional analysis of carnelian beads from the early Neolithic site of Nahal Hemar Cave, southern Levant. Journal of Archaeological Science, 58, 77-88. DOI: https://doi.org/10.1016/j.jas.2015.03.030

Hamilton, R. W. (1935): Excavations at Tell Abu Hawām. Quarterly of the Department of Antiquities in Palestine, 4: 1-69.

Harden, D. (1962): The Phoenicians. Bristol, Praeger.

Harrell, J. A.; Storemyr, P. (2009): Ancient Egyptian quarries - an illustrated overview. QuarryScapes: ancient stone quarry landscapes in the Eastern Mediterranean (N. Abu-Jaber, E. G. Bloxam, P. Degryse $\&$ T. Heldal, eds.), Oslo, Geological Survey of Norway, 7-50.

Hepper, N. (1990): Pharaoh's Flowers: The Botanical Treasures of Tutankhamun. London, Royal Botanical Gardens.

Herrmann, C. (1985): Formen für ägyptische Fayencen. Fribourg, Universitätsverlag.

Herrmann, C. (2006): Ägyptische Amulette aus Palästina/Israel: Band III. Fribourg, Academic Press.

Herrmann, C. (2016): Agyptische Amulette aus Palästina/Israel Band IV: Von der Spätbronzezeit IIB bis in römische Zeit. Fribourg, University Press.

Inizan, M.-L. (1999): La cornaline de l'Indus et la voie du Golfe au IIIe millénaire. Cornaline et pierres précieuses. La Mediterrannée, de l'Antiquité à l'Islam (A. Caubet, dir.), Paris, Réunion des Musées Nationaux: 125-38. 
Inizan, M.-L. (2000): Importation de cornalines et agates de l'Indus en Mésopotamie. Le cas de Suse et Tello. Cornaline de l'Inde. Des practiques techniques de Cambay aux techno-systèmes de l'Indus (V. Roux, ed.), Paris, Maison des Sciences de l'Homme: 473-501.

Jiménez Ávila, J. (ed.) (2017): Sidereum Ana III: El Río Guadiana y Tartesos. Mérida, Consorcio Ciudad de Mérida.

Lillios, K. (1999): Objects of Memory: The Ethnography and Archaeology of Heirlooms. Journal of Archaeological Theory and Method, 6(3): 235-62. DOI: https://doi.org/10.1023/A:1021999319447

López Castro, J. L. (2008): Las relaciones mediterráneas en el II milenio AC y comienzos del I en la Alta Andalucía y el problema de la 'Precolonización' Fenicia. Contacto cultural entre el Mediterráneo y el Atlántico (siglos XII-VIII ane). La precolonización a debate (S. Celestino, N. Rafel \& X. L. Armada, eds.), Madrid, CSIC: 273-88.

Lorrio, A. (2008): Qurénima. El Bronce Final del Sureste de la Península Ibérica. Madrid, Real Academia de la Historia.

Macalister, R. A. S. (1912): The Excavation of Gezer, 1902-1905 and 1907-1909. London, John Murray.

Martín de la Cruz, J. C. (1988): Mikenische Keramik aus bronzezeitliche Siedlungsschichte aus Montoro am Guadalquivir. Madrider Mitteilungen, 29: 77-91.

Martín de la Cruz, J. C. (coord.). (2004): Colgantes y cuentas de cornalina procedentes de Andalucía Occidental. Revista de Prehistoria, 3: 7-47.

Martín de la Cruz, J. C. (2008): El valle medio del Guadalquivir. Contacto cultural entre el Mediterráneo y el Atlántico (siglos XII-VIII ane). La precolonización a debate (S. Celestino, N. Rafel \& X. L. Armada, eds.), Madrid, CSIC: 289-99.

Martín de la Cruz, J. C.; Vera Rodríguez, J. C.; Gavilán Cevallos, B.; Perlines Benito, M. (2005): Un colgante de cornalina de manufactura oriental procedente de la província de Córdoba. El Período Orientalizante (S. Celestino Pérez \& J. Jiménez Ávila, eds.), Madrid, CSIC: 503-9.

Martín Ruiz, J. A. (2007): La crisis del siglo VI a.C. en los asentamientos fenicios de Andalucía. Málaga, Diputación.

Martínez Mira, I.; Vilaplana Ortego, E. (2014): Cuentas de collar de La Fonteta (Guardamar, Alicante) y La Peña Negra (Crevillente, Alicante): descripción y análisis instrumental. La Fonteta-2. Estudio de los materiales arqueológicos hallados en la colonia fenicia de la actual desembocadura del río Segura (Guardamar, Alicante) (A. González Prats, coord.), Alicante, Universidad de Alicante: 848-931.

Marzoli, D.; García Teyssandier, E. (2019): La necrópolis fenicia de Ayamonte (Huelva). Seville, Junta de Andalucía.

Marzoli, D.; Suárez Padilla, J.; Torres Ortiz, M. (2014): Die Meerenge östlich von Gibraltar am Übergang von der Bronze- zur Eisenzeit (9.-8. Jh. v. Chr.): Zum Forschungsstand. Madrider Mitteilungen, 55: $167-212$.

Mata Carriazo, J. de (1970): El tesoro y las primeras excavaciones de Ébora (Sanlúcar de Barrameda). Madrid, Ministerio de Educación Nacional.

Mata Carriazo, J. de (1973): Tartessos y el Carambolo. Madrid, Ministerio de Educación y Ciencia.

Mataloto, R. (2012): Os Senhores e as Serras: o final da Idade do Bronze no Alentejo Central. Sidereum Ana II. El río Guadiana en el Bronce Final (J. Jiménez Ávila, ed.), Madrid, CSIC: 182-213.

Matarasso, P.; Roux, V. (2000): Le système techno-économique des perles de cornaline

Modélisation des systèmes complexes de production par l'analyse d'activités. Cornaline de l'Inde. Des practiques techniques de Cambay aux techno-systèmes de l'Indus (V. Roux, ed.), Paris, Maison des Sciences de l'Homme: 337-410.

Matarese, I.; Crispino, A.; Jung, R.; Martinelli, M. C.; Pallante, P.; Pacciarelli, M. (2015): Vaghi e pendenti litici dell'età del bronzo dalla Sicilia e dalle Eolie. Archeologia Austriaca, 99: 111-53. DOI: https://doi. org/10.1553/archaeologia99s111

Mazar, A. (2004): The Family Tomb n.1 at the Northern Cemetery of Achziv (10th-6th centuries). Barcelona, Universidad Pompeu Fabra.

McGovern, P. (1985): Late Bronze Age Palestinian Pendants: Innovation in a Cosmopolitan Age. Sheffield, ASOR.

Merrillees, R. S. (1962): Opium Trade in the Bronze Age Levant. Antiquity, 36(144), 287-92. DOI: https:// doi.org/10.1017/S0003598X00036814

van de Mieroop, M. (2007): The Eastern Mediterranean in the Age of Ramesses II. London, Blackwell. 
Molina Fajardo, F.; Ruiz Fernández, A.; Huertas Jiménez, C. (1982): Almuñécar en la Antigüedad. La necrópolis fenicio- púnica de Puente de Noy. Granada, Caja de Ahorros de Granada.

Moutsiou, T.; Kassianidou, V. (2019): Geochemical characterization of carnelian beads from Aceramic Neolithic Cyprus using portable X-ray Fluorescence Spectrometry (pXRF). Journal of Archaeological Science: Reports, 25: 257-65. DOI: https://doi.org/10.1016/j.jasrep.2019.04.013

Müller-Winckler, C. (1987): Die Ägyptischen Objekt-Amulette. Göttingen, Vandenhoeck \& Ruprecht.

Nicolini, G. (1991): Techniques des ors antiques. La bijouterie ibérique du VIIe au IVe siècle. Paris, Picard.

Padró, J. (1980-5): Egyptian-Type Documents from the Mediterranean Littoral of the Iberian Peninsula before the Roman Conquest. Leiden, Brill.

Padró, J. (1995): New Egyptian-Type Documents from the Mediterranean Littoral of the Iberian Peninsula before the Roman Conquest. Montpellier, Université Paul Valéry.

Perdigones, L.; Muñoz, A.; Pisano, G. (1990): La necropolis fenicio-púnica de Cádiz. Roma, Universitá degli Studi di Roma.

Pereira, C. (2018): As necrópoles romanas do Algarve: acerca dos espaços da morte no extremo Sul da Lusitânia. Lisbon, INCM.

Pérez Macías, J. A.; Cabaco Encinas, B.; García Teyssandier, E. (2017): Primer avance sobre el asentamiento fenicio de Ayamonte (Huelva). In Jiménez Ávila 2017: 467-92.

Phillips, J. (2003): An unconsidered trifle. The synchronization of civilizations in the Eastern Mediterranean in the Second Millennium B.C. II (M. Bietak, ed.), Vienna, ÖAW: 545-50.

Phillips, J. (2008): Aegyptiaca on the island of Crete in their chronological context: A Critical Review. Vienna, ÖAW.

Quillard, B. (1979): Bijoux Carthaginois, I. Les colliers. Leuven, University of Leuven.

Reade, J. E. (1979): Early Etched Beads and the Indus-Mesopotamia Trade. London, British Museum.

Reiterman, A. S. (2016): Keimêlia: Objects Curated in the Ancient Mediterranean (8th-5th Centuries B.C.). $\mathrm{PhD}$ Thesis, University of Pennsylvania.

Reuther, O. (1926): Die Innenstadt von Babylon (Merkes). Leipzig, J. C. Heinrichs'sche Buchhandlung.

Rigaud, S.; Serrand, N.; Guilaine, J. (2017): Les parures des premières sociétés du Néolithique précéramique de Chypre: apport des gisements de Klimonas et de Shillourokambos. Nouvelles données sur les débuts du Néolithique à Chypre (J.-D. Vigne, F. Briois \& M. Tengberg, dirs.), Paris, Société Préhistorique Française: 183-98.

Rodríguez de Berlanga, M. (1891): El nuevo bronce de Itálica. Málaga, Imprenta de Ambrosio Rubio.

Roux, V. (ed.) (2000): Cornaline de l'Inde. Des practiques techniques de Cambay aux techno-systèmes de l'Indus. Paris, Maison des Sciences de l'Homme.

Ruiz Gil, J. A.; López Amador, J. J. (2001): Formaciones sociales agropecuarias en la Bahía de Cádiz. 5000 años de adaptación ecológica en la Laguna del Gallo, El Puerto de Santa María. Cádiz, Arqueodesarrollo Gaditano.

Ruiz Gil, J. A.; López Amador, J. J. (2004): Las piezas de la cabaña de Pocito Chico en su contexto (Puerto de Santa María, Cádiz). In Martín de la Cruz 2004: 11-4.

Ruiz Mata, D.; Pérez Pérez, C. (1995): El Poblado Fenicio del Castillo de Doña Blanca (El Puerto de Santa María, Cádiz). Puerto de Santa María, Ayuntamiento.

Ruiz Mata, D.; Pérez Pérez, C.; Martín de la Cruz, J. C. (2004): Colgante procedente del yacimiento de la Sierra de San Cristóbal (Puerto de Santa María, Cádiz). In Martín de la Cruz 2004: 10-1.

Ruiz-Gálvez Priego, M. (2009): ¿Qué hace un micénico como tú en un sitio como éste? Andalucía entre el colapso de los palacios y la presencia semita. Trabajos de Prehistoria, 66(2): 93-118. DOI: https://doi. org/10.3989/tp.2009.09028

Sánchez Romero, A.; Martín de la Cruz, J. C. (2004): Colgante procedente de Córdoba (Castro del Río, Córdoba). In Martín de la Cruz 2004: 9-10.

Schubart, H.; Niemeyer, H. G. (1976): Trayamar. Los hipogeos fenicios y el asentamiento en la desembocadura del río Algarrobo. Madrid, Ministerio de Educación y Ciencia.

Soares, R. M.; Baptista, L.; Pinheiro, R.; Oliveira, L.; Rodrigues, Z.; Vale, N. (2017): A necrópole da I Idade do Ferro do Monte do Bolor 1-2 (São Brissos, Beja). In Jiménez Ávila 2017: 263-302.

Suárez Padilla, J. (2018): Comunidades autóctonas y expansión fenicia a las puertas del Estrecho de Gibraltar (2.200 A.C.-600 A.C.). PhD Thesis, Complutense University of Madrid.

Torres Ortiz, M. (1999): Sociedad y Mundo Funerario en Tartessos. Madrid, Real Academia de la Historia. Torres Ortiz, M. (2002): Tartessos. Madrid, Real Academia de la Historia. 
Torres Ortiz, M. (2008): Los «tiempos» de la precolonización. Contacto cultural entre el Mediterráneo y el Atlántico (siglos XII-VIII ane). La precolonización a debate (S. Celestino, N. Rafel \& X. L. Armada, eds.), Madrid, CSIC: 59-91.

Torres Ortiz, M. (2013): Los colgantes de cornalina de Mesas de Asta. La pieza del mes, Abril 2013: 1-3.

Tubb, J. N. (1988): Tell es-Sa'idiyeh. Preliminary Report on the First Three Seasons of Renewed Excavations. Levant, 20(1): 23-88. DOI: https://doi.org/10.1179/lev.1988.20.1.23

Veiga, S. E. da (1891): Antiguidades Monumentaes do Algarve, 4. Faro, University of Algarve.

Vera Rodríguez, J. C. (1999): El Calcolítico en el Alto Valle del Guadiato: los hábitats y las necrópolis prehistóricas del entorno de Sierra Palacios (Belmez, Córdoba). PhD Thesis, University of Córdoba.

Vera Rodríguez, J. C. (2004): Colgante procedente de los Castillejos de la Granjuela (Córdoba). In Martín de la Cruz 2004: 8-9.

Vives y Escudero, A. (1917): Estudio de Arqueología Cartaginesa. La necrópolis de Ibiza. Madrid, Junta para la Ampliación de Estudios e Investigaciones Científicas.

Xia, N. (2014): Ancient Egyptian Beads. Berlin, Springer. 